\title{
Article \\ 4-(Phenylsulfanyl) Butan-2-One Attenuates the Inflammatory Response Induced by Amyloid- $\beta$ Oligomers in Retinal Pigment Epithelium Cells
}

\author{
Peeraporn Varinthra ${ }^{1}$, Shun-Ping Huang ${ }^{2}$, Supin Chompoopong ${ }^{3}$, Zhi-Hong Wen ${ }^{4}\left(\mathbb{D}\right.$ and Ingrid Y. Liu ${ }^{1, *(D)}$ \\ 1 Institute of Medical Sciences, Tzu Chi University, Hualien 970, Taiwan; vpeeraporn@gms.tcu.edu.tw \\ 2 Department of Molecular Biology and Human Genetics, Tzu Chi University, Hualien 970, Taiwan; \\ sphophdoc1688@gms.tcu.edu.tw \\ 3 Department of Anatomy, Faculty of Medicine Siriraj Hospital, Mahidol University, Bangkok 10700, Thailand; \\ supin.cho@mahidol.ac.th \\ 4 Department of Marine Biotechnology and Resources, National Sun Yat-sen University, Kaohsiung 804, \\ Taiwan; wzh@mail.nsysu.edu.tw \\ * Correspondence: ycliu@gms.tcu.edu.tw; Tel.: +886-3846-2722
}

Citation: Varinthra, P.; Huang, S.; Chompoopong, S.; Wen, Z.; Liu, I.Y. 4-(Phenyls-ulfanyl) Butan-2-One Attenuates the Inflammatory Response Induced by Amyloid- $\beta$ Oligomers in Retinal Pigment Epithelium Cells. Mar. Drugs 2021, 19, 1. https:/ /dx.doi.org/ 10.3390/md19010001

Received: 1 November 2020 Accepted: 22 December 2020 Published: 23 December 2020

Publisher's Note: MDPI stays neutral with regard to jurisdictional claims in published maps and institutional affiliations.

Copyright: (c) 2020 by the authors. Licensee MDPI, Basel, Switzerland. This article is an open access article distributed under the terms and conditions of the Creative Commons Attribution (CC BY) license (https: / / creativecommons.org/ licenses/by/4.0/).
Abstract: Age-related macular degeneration (AMD) is a progressive eye disease that causes irreversible impairment of central vision, and effective treatment is not yet available. Extracellular accumulation of amyloid-beta $(A \beta)$ in drusen that lie under the retinal pigment epithelium (RPE) has been reported as one of the early signs of AMD and was found in more than $60 \%$ of Alzheimer's disease (AD) patients. Extracellular deposition of $\mathrm{A} \beta$ can induce the expression of inflammatory cytokines such as IL- $1 \beta$, TNF- $\alpha$, COX-2, and iNOS in RPE cells. Thus, finding a compound that can effectively reduce the inflammatory response may help the treatment of AMD. In this research, we investigated the anti-inflammatory effect of the coral-derived compound 4-(phenylsulfanyl) butan2-one (4-PSB-2) on $A \beta_{1-42}$ oligomer $\left(\mathrm{o} A \beta_{1-42}\right)$ added to the human adult retinal pigment epithelial cell line (ARPE-19). Our results demonstrated that 4-PSB-2 can decrease the elevated expressions of TNF- $\alpha$, COX-2, and iNOS via NF- $\mathrm{kB}$ signaling in ARPE-19 cells treated with $\mathrm{oA} \beta_{1-42}$ without causing any cytotoxicity or notable side effects. This study suggests that 4-PSB-2 is a promising drug candidate for attenuation of AMD.

Keywords: coral; 4-(Phenylsulfanyl) Butan-2-One; inflammatory responses; amyloid- $\beta$; retinal pigment epithelium cells

\section{Introduction}

Age-related macular degeneration (AMD) is a degenerative macular disease that causes vision loss in the aged population [1]. It can be categorized into wet (neovascular AMD) and dry (atrophic AMD) AMD. The wet type is found in around $10-20 \%$ of AMD patients and results from abnormal growth of blood vessels. The breaking and leakage of blood vessels leads to irreversible damage to the macula and photoreceptors, in turn leading to vision loss. Blocking the activity of vascular endothelial growth factor (VEGF) is used as a treatment for wet-type AMD [2,3], whereas there is no approach yet for treating dry-type AMD. The dry-type AMD shows slower progression than wet-type AMD, and it affects approximately $80-90 \%$ of AMD patients. It is also associated with the formation of drusen [4]. Drusen are small yellow deposits in the macular area and are a common pathological hallmark of early AMD. Increased size and number of drusen contribute to a higher risk of AMD development and are related to retinal pigment epithelium (RPE) dysfunction, RPE atrophy, and photoreceptor degeneration [5,6]. The RPE is a monolayer of pigmented cells derived from the neuroectoderm and is located in between the neurosensory retina and the vascular choroid. The important functions of RPE cells are to maintain homeostasis of the outer retina, including helping the absorption of light, 
phagocytosis of old rod outer segments, transportation of nutrients and ions, protection from oxidative stress, immune privilege, and secretion of cytokines $[7,8]$. The amyloidbeta $(A \beta)$ aggregates existing in drusen are related to increased secretion of inflammatory cytokines from RPE cells [9].

A $\beta$ peptide contains $39-43$ amino acids and presents mainly in senile amyloid plaques in the brain of Alzheimer's disease (AD) patients and in the drusen of AMD patients $[6,10,11]$. In eyes, $A \beta$ aggregation is primarily located among the outer segments of photoreceptors and between the RPE and Bruch's membranes. oA $\beta_{1-42}$ secretion is elevated in human RPE cells by aging and is associated with oxidative stress [12], autophagy [13], and expressions of inflammatory molecules such as interleukin (IL)- $1 \beta$, IL-6, tumor necrosis factor- $\alpha$ (TNF- $\alpha$ ), cyclooxygenase-2 (COX-2), and inducible nitric oxide synthase (iNOS) [14, 15]. These inflammatory-related cytokines and molecules were also increased in AMD patients [16-18]. Therefore, finding and developing a novel compound that can effectively reduce the inflammatory response in retinal cells is urgent for treating AMD.

In the past decade, more than $20 \%$ of novel marine compounds have been discovered from soft corals [19]. The natural products isolated from soft corals have been demonstrated to exhibit various biological activities such as anti-tumor, anti-viral, and anti-inflammatory functions with minimum adverse effects [19-23]. The compound 4-(phenylsulfanyl) butan2-one (4-PSB-2), modified from dihydroaustrasulfone alcohol, is synthetic precursor of soft coral (Cladiella australis)-derived natural compound, austrasulfone. It has an antimelanogenic effect via the suppression of tyrosine kinase activity in zebrafish embryos [24] It can also reduce expression levels of iNOS, and COX-2 increased after the optic nerves of rats were crushed [25]. Based on these lines of evidence, we investigated whether 4-PSB-2 can suppress inflammatory responses in human adult retinal pigment epithelial cell line (ARPE-19 cells) treated with oA $\beta_{1-42}$. Here, we report that 4-PSB-2 can effectively reduce the expressions of TNF- $\alpha, C O X-2$, and iNOS via NF- $\mathrm{KB}$ signaling in $\mathrm{OA} \beta_{1-42}$-treated ARPE-19 cells without notable cytotoxicity. Our results suggest that 4-PSB-2 is a promising therapeutic compound for treating AMD.

\section{Results}

\subsection{The Addition of oA $\beta_{1-42}$ Caused Morphological Changes and Mild Cell Death in ARPE-19 Cells}

RPE cells are the major cell type affected by oA $\beta_{1-42}$ in AMD [26]. To investigate the effect of adding $\mathrm{OA} \beta_{1-42}$ in ARPE-19 cells, the $\mathrm{A} \beta$ peptide was incubated at $37^{\circ} \mathrm{C}$ for $24 \mathrm{~h}$, and the presence of the oligomeric form was further confirmed by immunocytochemistry staining of $\mathrm{A} 11$ or $\mathrm{A} \beta$ oligomer markers (Figure 1A). Three different concentrations of $\mathrm{oA} \beta_{1-42}(0.1,1$, and $10 \mu \mathrm{M})$ were administered to ARPE-19 cells for $48 \mathrm{~h}$. Then, the thiazolyl blue tetrazolium blue (MTT) assay was performed and showed no significant cell death $(\mathrm{F}(3,30)=0.792, p=0.513 ;$ Figure 1B). However, the morphological changes were observed in the $10 \mu \mathrm{M}$ of oA $\beta_{1-42}$ group. Cell bodies and nuclei of ARPE-19 cells with added $\mathrm{oA} \beta_{1-42}$ became smaller, and the cytoplasm contained many small vesicles (Figure 1C), which were suspected to be autophagosomes. Autophagy is a self-clearance mechanism that leads to the transport of cytoplasmic materials to vesicles for degradation and recycling. Autophagic dysfunction has been observed in AMD and is linked to the progression of disease $[27,28]$. To determine whether the small vesicles observed in the oA $\beta_{1-42}$-treated ARPE-19 cells were autophagosomes, we investigated the expression of autophagy-related molecules in $\mathrm{oA} \beta_{1-42}$-treated ARPE-19 cells. Expressions of several autophagy-related molecules including LC3B I (Figure 2B), LC3B II (Figure 2C), BECLIN 1 (Figure 2D), and p62 (Figure 2E) were detected, indicating the existence of autophagasomes. p62 expression was decreased, suggesting an increase in autophagic activity. 
A

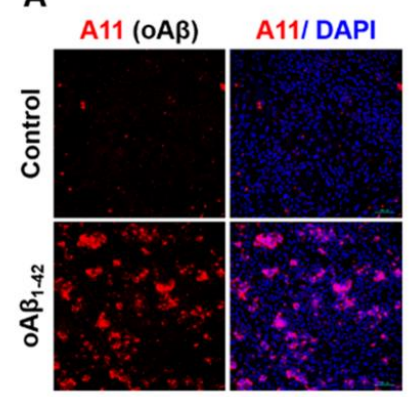

D

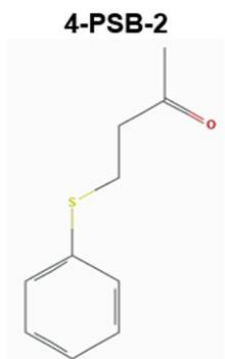

B

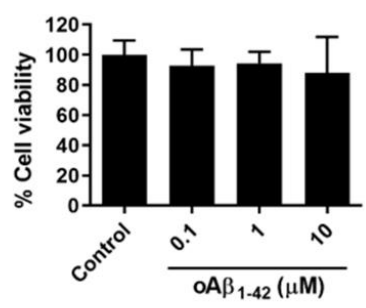

E

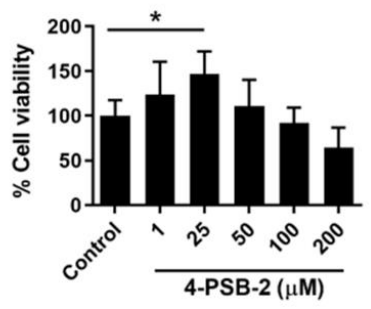

C

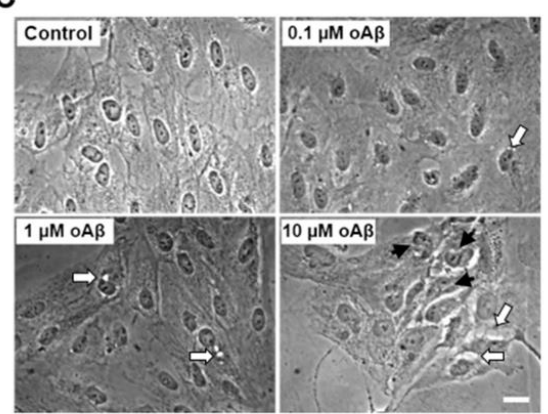

Figure 1. The effects of $\mathrm{oA} \beta_{1-42}$ and 4-PSB-2 on the viability of human adult retinal pigment epithelial cell line (ARPE-19 cells). (A) The expression of oA $\beta_{1-42}$ in ARPE-19 cells: A11 (red), oA $\beta$ marker; DAPI (blue), nucleus; Bar, $100 \mu \mathrm{m}$. (B) A dose-response curve for RPE cells stimulated with 0.1 to $10 \mu \mathrm{M}$ solutions of oA $\beta_{1-42}$ for $48 \mathrm{~h}$ demonstrates the mild effect of $10 \mu \mathrm{M}$ oA $\beta_{1-42}$ on the viability of ARPE-19 cells ( $n=5-6 /$ group). (C) The morphology of ARPE-19 cells after 0.1 to $10 \mu \mathrm{M}$ of oA $\beta_{1-42}$ treatment compared to control; Bar, $20 \mu \mathrm{m}$. The irregular shapes of cell bodies and nuclei of ARPE-19 cells (black arrows) and small vesicles in the cytoplasm (white arrows) were observed after oA $\beta_{1-42}$ treatment. (D) Chemical structure of 4-PSB-2. (E) ARPE-19 cells were treated with $0.1 \%$ dimethyl sulfoxide (DMSO) in control, 4-PSB-2 $(1,25,50,100$, and $200 \mu \mathrm{M})$ for $24 \mathrm{~h}$. MTT analysis showed that 4-PSB-2 was not toxic to ARPE-19 cells, and $25 \mu \mathrm{M}$ of 4-PSB-2 significantly increased cell viability. ( ${ }^{*}$ indicates $p \leq 0.001$ between the groups).

\subsection{4-PSB-2 Increased Cell Viability in ARPE-19 Cells}

To examine the cytotoxic effect of 4-PSB-2 (Figure 1D) on ARPE-19 cells, we first applied five different concentrations of 4-PSB-2 (1, 25, 50, 100, and $200 \mu \mathrm{M})$ to ARPE-19 cell cultures for $24 \mathrm{~h}$, and we used the MTT assay to measure cell viability. Results of the MTT analysis indicated that 4-PSB-2 did not cause toxicity in ARPE-19 cells; on the other hand, $25 \mu \mathrm{M}$ of 4-PBS-2 significantly enhanced cell viability $(\mathrm{F}(5,28)=6.818, p<0.001$; Figure $1 \mathrm{E})$.

\subsection{4-PSB-2 Repressed Elevated Expression of Inflammation Markers in oA $\beta_{1-42}$-Treated ARPE-19 Cells}

4-PSB-2 has been reported to have anti-inflammatory and neuroprotective effects via inhibiting iNOS and COX-2 expression in a rat optic nerve crush model [25]. We thus wanted to investigate whether it had the same effects on oA $\beta_{1-42}$-treated ARPE-19 cells. MTT results are demonstrated in Figure 1E. ARPE-19 cells were administered with $10 \mu \mathrm{M}$ of $\mathrm{oA} \beta_{1-42}$, and $24 \mathrm{~h}$ later 4-PSB-2 was added, and cells were allowed to rest for an additional $24 \mathrm{~h}$ (Figure 3A). Then, the expression levels of inflammatory cytokines were measured. We detected higher expression levels of inflammatory cytokines including TNF- $\alpha$, COX2 , and iNOS after $10 \mu \mathrm{M}$ of oA $\beta_{1-42}$ administration. Notably, treatment with 4-PSB-2 significantly reduced the increased expression levels of TNF- $\alpha(\mathrm{F}(3,32)=28.767, p<0.001$; $\mathrm{F}(3,16)=5.852, p<0.01$; Figure 3B-D), COX-2 $(\mathrm{F}(3,32)=10.484, p<0.001 ; \mathrm{F}(3,16)=7.192$, $p<0.01$; Figure 3E-G), and iNOS $(\mathrm{F}(3,32)=9.977, p<0.001 ; \mathrm{F}(3,12)=23.169, p<0.001$; Figure $3 \mathrm{H}-\mathrm{J})$. We also investigated the effect of 4 -PSB-2 in oA $\beta_{1-42}$-treated ARPE-19 cells on the expression of autophagy-related molecules. The results indicated that $25 \mu \mathrm{M}$ of 
4-PSB-2 treatment did not significantly decrease the expression levels of autophagy-related molecules $\left(\mathrm{F}_{3,12}\right)=0.641, p=0.603, \mathrm{~F}(3,12)=1.786, p=0.203, \mathrm{~F}(3,12)=0.750, p=0.543$, $\mathrm{F}(3,12)=6.299, p<0.01$; Figure 2B-E).

A
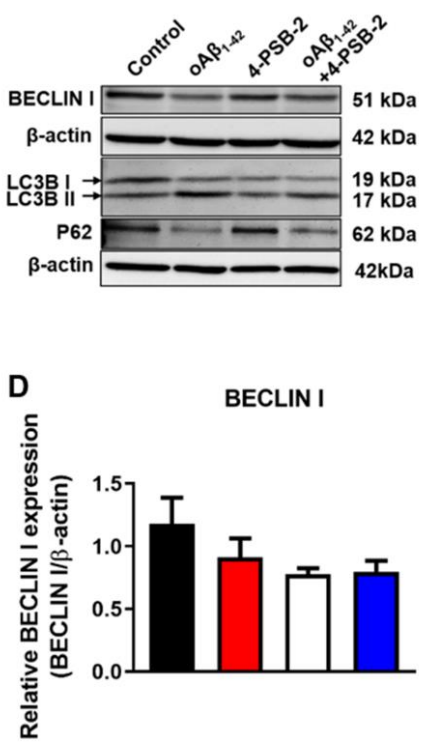

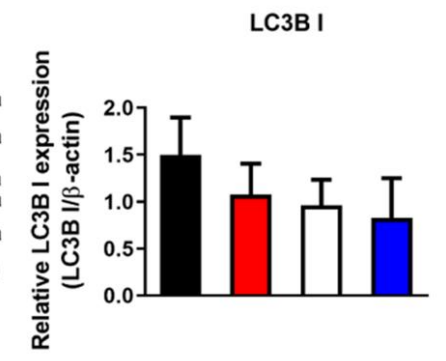

$\mathrm{E}$
C $\square \begin{gathered}\text { Control } \\ \mathrm{OA} \beta_{1-42}\end{gathered}$

LC3B II

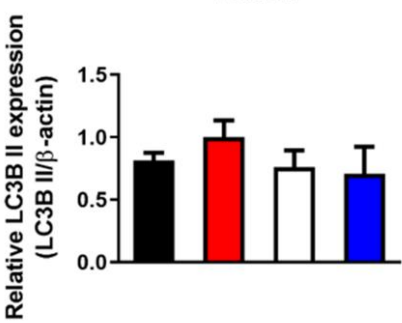

Figure 2. The effects of 4-PSB-2 on the autophagy markers expression in oA $\beta_{1-42}$-induced ARPE-19 cells. The experimental design is shown in Figure 3A. (A) The expressions of BECLIN 1, LC3B I, LC3B II, and p62 in ARPE-19 cells were assessed by Western blotting. (B-E) Quantitative analysis of the expressions of BECLIN 1, LC3B I, LC3B II, and p62 in ARPE-19 cells treated with the 4-PSB-2 and/or oA $\beta_{1-42}$. (B-D) The expression levels of BECLIN 1, LC3B I, and LC3B II were not significantly different between the groups after $\mathrm{oA} \beta_{1-42}$ and/or 4-PSB-2 treatment. (E) The expression of $\mathrm{p} 62$ in the $\mathrm{o} A \beta_{1-42}$ group was significantly decreased compared to the control group but was not rescued by 4-PSB-2 treatment. The results were plotted as means \pm SEMs, ${ }^{*}$ indicates $p \leq 0.05$ between the groups.

\subsection{4-PSB-2 Attenuates Inflammatory Responses through NF- $\kappa B$ Signaling in ARPE-19 Cells}

$\mathrm{NF}-\mathrm{KB}$ is a key mediator that regulates the inflammatory response through TNF- $\alpha$ activation [29]. It is also an upstream regulator of COX-2 and iNOS [30]. Next, we asked whether the anti-inflammatory effect of 4-PSB-2 on oA $\beta_{1-42}$-treated ARPE-19 cells was mediated by NF- $\mathrm{kB}$ signaling. The expression of NF- $\mathrm{kB}$ p65 was detected in $\mathrm{oA} \beta_{1-42}$ treated ARPE-19 cells by immunocytochemical staining and Western blot analysis. oA $\beta_{1-42}$ treatment for $48 \mathrm{~h}$ significantly enhanced NF- $\mathrm{KB}$ p65 expression. Notably, treatment with 4-PSB-2 significantly inhibited the increased expression levels of NF- $\mathrm{KB}$ p65 $(\mathrm{F}(3,32)=55.397$, $p<0.001 ; \mathrm{F}(3,16)=4.607, p<0.01 ;$ Figure $4 \mathrm{~A}-\mathrm{C})$ induced by oA $\beta_{1-42}$. 


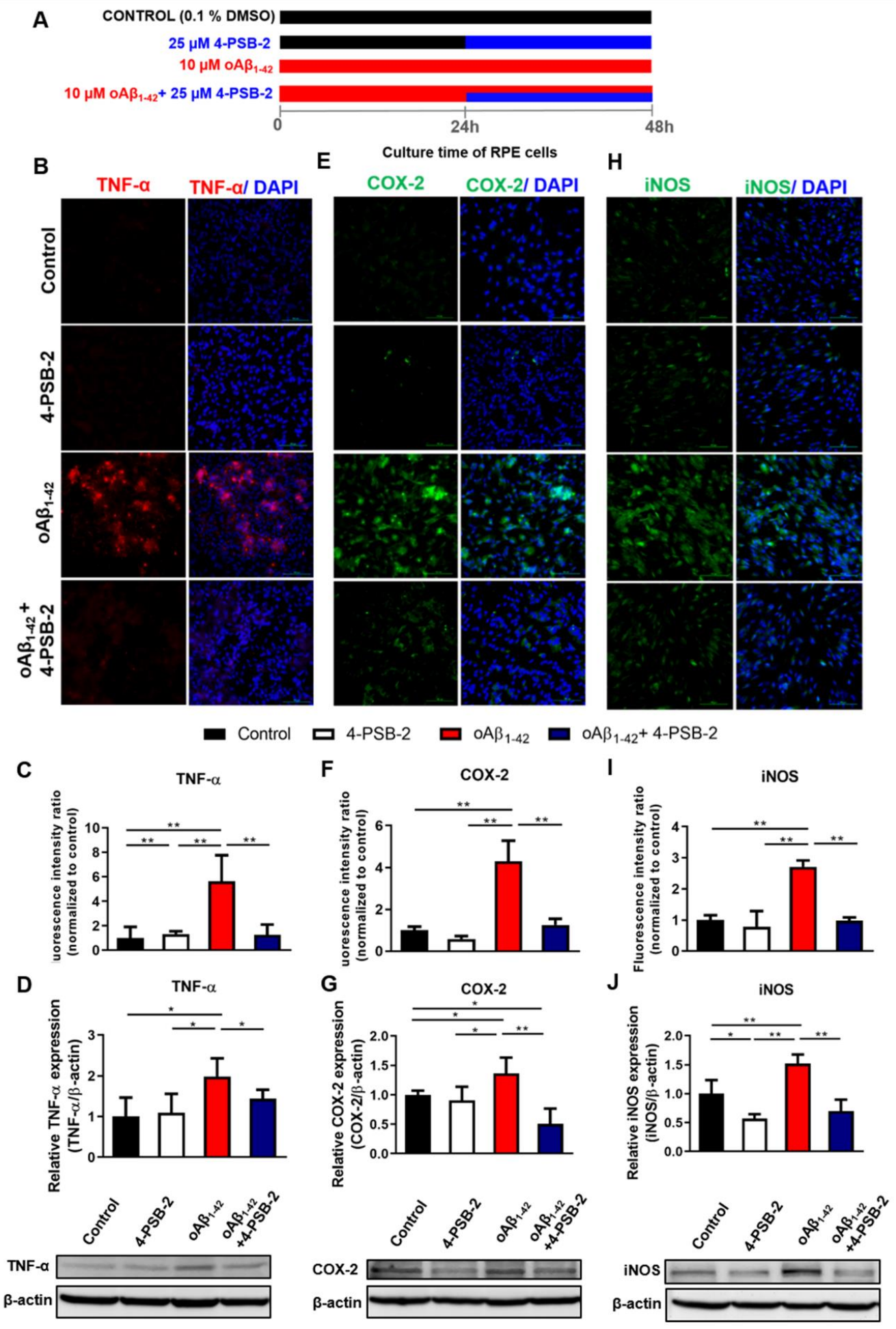

Figure 3. The effects of 4-PSB-2 on oA $\beta_{1-42}$-induced expression of inflammatory markers in ARPE-19 cells. (A) The illustrated protocols of ARPE-19 cells added with 4-PSB-2 and/or oA $\beta_{1-42}$. The ARPE-19 cells were cultured for a total of $48 \mathrm{~h}$. For the control group, $0.1 \%$ dimethyl sulfoxide (DMSO) was added only. Twenty-five micromolars of 4-PSB-2 was added after the cells cultured for $24 \mathrm{~h}$ (from $24 \mathrm{~h}$ to $48 \mathrm{~h}$ ) to test drug-only effects. To test the effects of 4 -PSB-2 on the $\mathrm{oA} \beta_{1-42}$-induced inflammatory response, in the cell cultures treated with $10 \mu \mathrm{M} \mathrm{oA} \beta_{1-42}, 25 \mu \mathrm{M}$ of 4 -PSB-2 was added from $24 \mathrm{~h}$ to $48 \mathrm{~h}$. Fluorescence immunocytochemical staining and Western blot analysis of (B-D) TNF- $\alpha,(\mathrm{E}-\mathrm{G}) \mathrm{COX}-2$, and (H-J) iNOS expressions were significantly increased in oA $\beta_{1-42}$-treated ARPE-19 cells and decreased after 4-PSB-2 administration for $24 \mathrm{~h}$. The results are plotted as means \pm SEMs. * indicates $p \leq 0.05$, and ** indicates $p \leq 0.001$ between the groups. TNF- $\alpha$ (red), COX-2 and iNOS (green), and DAPI (blue) (nuclei), Bar $=100 \mu \mathrm{m}$. 
A

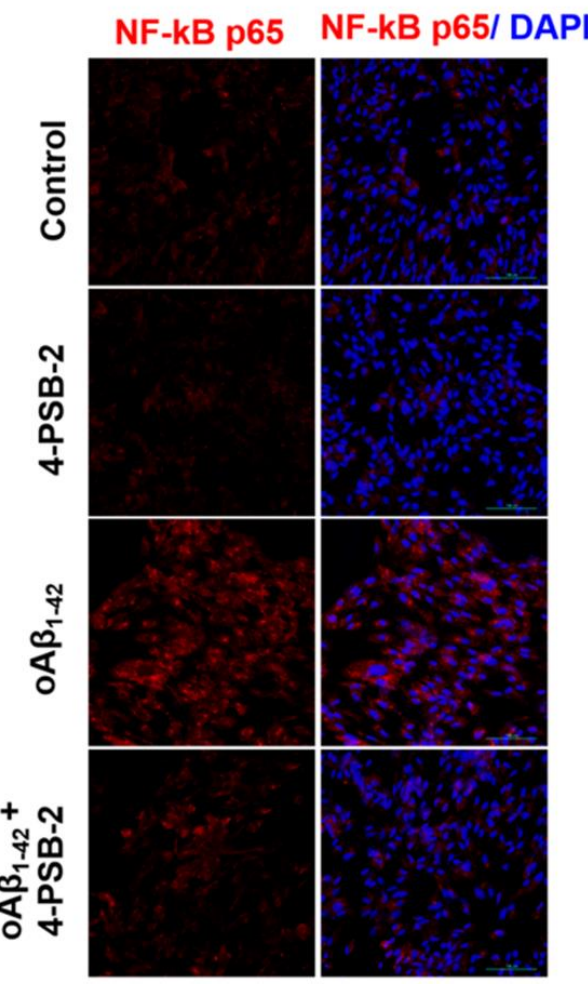

- Control $\square$ 4-PSB-2

$\mathrm{OA} \beta_{1-42} \mathrm{OA} \beta_{1-42}+4-\mathrm{PSB}-2$

B

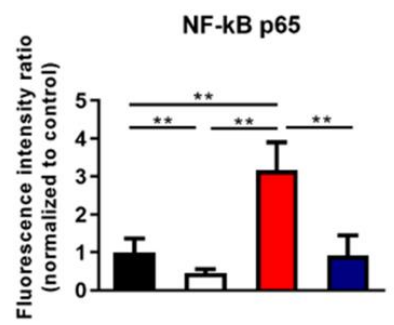

C

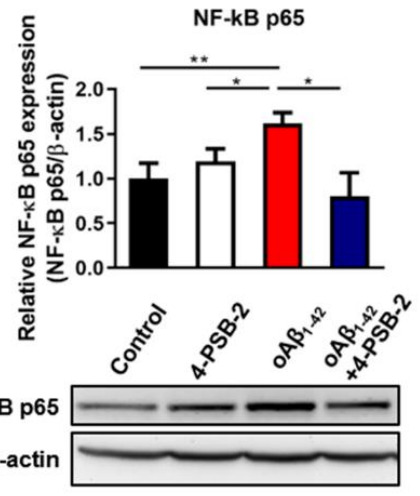

Figure 4. The effect of 4-PSB-2 on NF-kB signaling in ARPE-19 cells treated with oA $\beta_{1-42}$. (A,B) Fluorescence immunocytochemical staining and the quantitative results of NF- $\mathrm{B}$ p65 expression in ARPE-19 cells were significantly enhanced after $\mathrm{OA} \beta_{1-42}$ administration for $48 \mathrm{~h}$. This phenomenon was suppressed with co-treatment of $\mathrm{oA} \beta_{1-42}$ and 4-PSB-2. These results were reconfirmed with Western blot analysis $(\mathbf{C})$. The results are plotted as means \pm SEMs. ${ }^{*}$ indicates $p \leq 0.05$, and ${ }^{* *}$ indicates $p \leq 0.001$ between the groups. NF- kB p65 (red), and DAPI (blue) (nuclei); Bar, $100 \mu \mathrm{m}$.

\section{Discussion}

In the present study, we demonstrated that 4-PSB-2 has anti-inflammatory effects on $\mathrm{oA} \beta_{1-42}$-treated ARPE-19 cells. The compound 4-PSB-2 can effectively suppress overexpression of TNF- $\alpha$, COX-2, and iNOS via NF-KB signaling in ARPE-19 cells induced by $\mathrm{oA} \beta_{1-42}$ treatment without causing any notable side effects (Figure 5).

Previous studies have reported that exposure of ARPE- 19 cells to oA $\beta$ resulted in a reduction in cell viability in a dose- and time-dependent pattern [14,31]. Our results are in line with an earlier study showing that $10 \mu \mathrm{M}$ of oA $\beta$ can alter the structure and function of RPE cells [5], but not cause cell death. It is noted that different concentrations of $\mathrm{OA} \beta$ added to ARPE-19 cells cause distinct degrees of change. Five micromolars of oA $\beta$ increased ARPE-19 cell proliferation and inhibited apoptosis, whereas significant ARPE-19 cell death was observed after treatment with $25 \mu \mathrm{M}$ of oA $\beta$ for $48 \mathrm{~h}$ [32]. Here, we found that the morphology of ARPE-19 cells was changed, with shrinking cell bodies and nuclei, and filling small vesicles in the cytoplasm. Transmission electron microscopy identified that the small vesicles were autolysosomes and autophagosomes [13]. Our results revealed that the p62-autophagy marker was decreased in ARPE-19 cells treated with oA $\beta$ peptides, which supports the findings from the aforementioned study. p62 directly binds to microtubule-associated protein 1A/1B-light chain 3 (LC3) to negatively modulate autophagic activity $[13,33]$. In addition, we found that expressions of inflammatory markers including TNF- $\alpha$, COX-2, and iNOS were increased via NF-KB signaling in ARPE-19 cells induced with oA $\beta_{1-42}$, which were consistent with studies on human RPE cells exposed to $\mathrm{oA} \beta_{1-42}[14,15]$ and AMD patients [16-18]. Interestingly, a study in the Russian population also reported a significant association between AMD and single-nucleotide polymorphisms of TNF- $\alpha$ [34]. TNF- $\alpha$, a proinflammatory cytokine, is synthesized and secreted by ac- 
tivated macrophages and T-cells, and it regulates the biological activities of cells [35]. Chronic activation of TNF- $\alpha$ in RPE cells can change cell morphology, alter tight-junction organization, and decrease the immunosuppressive capacities by inducing transforming growth factor $\beta$ (TGF- $\beta$ ) expression [36]. The activation of TNF- $\alpha$ is mediated by NF- $\mathrm{kB}$, which is the upstream mediator of COX-2 and iNOS [29]. Inhibition of NF-kB signaling can reduce the inflammatory expressions and angiogenic factors in RPE cells induced by $\mathrm{oA} \beta_{1-42}$ [37]. COX-2 is an enzyme inducible by pathologic stimuli such as lipopolysaccharides, IL- $1 \beta$, TNF- $\alpha$, and NF- $\mathrm{KB}$ [38]. Previous studies have shown that the expression of COX-2 in human choroidal neovascular membranes was related to AMD pathology by increasing the secretion of VEGF and TGF- $\beta[38,39]$. iNOS is an inducible isoform of nitric oxide and is induced by inflammatory cytokines. The increase in iNOS expression in choroidal neovascular membranes from patients with AMD directly links with VEGF [40]. Taken together, the overexpressions of inflammatory cytokines presented in ARPE-19 cells induced by oA $\beta_{1-42}$ may be one of the causal factors of AMD; thus, reduction in the inflammatory response may become an effective therapeutic approach for this disease.

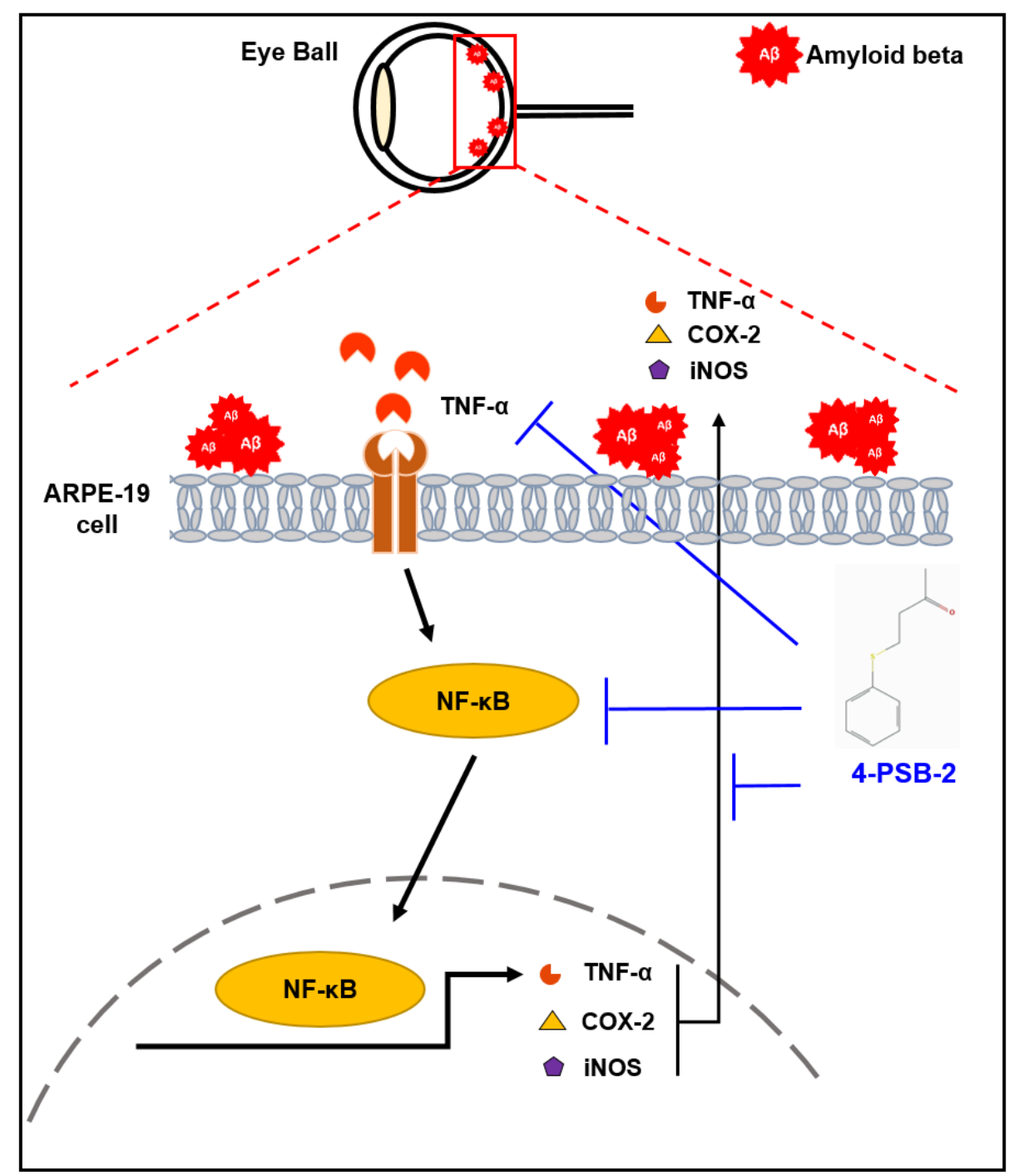

Figure 5. The effects of 4-PSB-2 in oA $\beta_{1-42}$-induced ARPE-19 cells. The extracellular deposition of $\mathrm{oA} \beta_{1-42}$ increased expressions of TNF- $\alpha$, COX-2, and iNOS in ARPE-19 cells via NF- $\mathrm{kB}$ signaling. Expressions of these inflammatory markers were suppressed by 4-PSB-2 treatment.

The compound 4-PSB-2, modified from dihydroaustrasulfone alcohol, is a synthetic precursor of Cladiella australis-derived natural compound, austrasulfone. Both austrasul- 
fone and dihydroaustrasulfone alcohol are anti-inflammatory compounds that can inhibit the expressions of iNOS and COX-2 proteins in LPS-stimulated RAW264.7 macrophage cells [22]. Besides, the chemical structure of 4-PSB-2 is similar to BAY 11-7082, which also shows anti-inflammatory effects via NF- $\mathrm{kB}$ signaling [41]. Thus, the two compounds probably repress the inflammatory response via a similar mechanism. However, $25 \mu \mathrm{M}$ of 4-PSB-2 did not modulate autophagic activity. Either $25 \mu \mathrm{M}$ is not an effective dosage to rescue autophagic dysfunction, or this compound does not affect the autophagy pathway. Our results suggest that 4-PSB-2 may be a promising drug candidate for treating AMD. Further time-course, pharmacokinetic, and pharmacological metabolism studies are necessary to explore the possibility of further clinical application.

\section{Materials and Methods}

\subsection{Cell Culture}

A human retinal pigment epithelial cell line (ARPE-19) was provided by Rong-Kung Tsai at Institute of Medical Sciences, Tzu Chi University (Taiwan), and cultured in Dulbecco's modified Eagle's medium/nutrient mixture F-12 (DMEM/F12), containing 10\% fetal bovine serum (FBS), $100 \mathrm{U} / \mathrm{mL}$ penicillin, and $100 \mu \mathrm{g} / \mathrm{mL}$ streptomycin at $37^{\circ} \mathrm{C}$ in $5 \% \mathrm{CO}_{2}$ and $95 \%$ air. All cell culture reagents were obtained from Thermo Fisher Scientific (Waltham, MA, USA). The cells were seeded in 24-well plates $\left(1 \times 10^{5}\right.$ cells/well $)$ on $12 \times 12 \mathrm{~mm}^{2}$ pieces of glass for immunocytochemical staining, 6-well plates $\left(7 \times 10^{5}\right.$ cells /well) for protein collection, and 96-well plates $\left(2 \times 10^{4}\right.$ cells/well $)$ for cell viability assays.

\subsection{Preparation of Oligomeric $A \beta_{1-42}$ Solution}

The $\mathrm{A} \beta_{1-42}$ peptide (Bacham, Merseyside, UK) was dissolved in $0.1 \% \mathrm{NH}_{4} \mathrm{OH}$ to a final concentration of $1 \mathrm{mg} / \mathrm{mL}$. The $\mathrm{A} \beta_{1-42}$ peptide was incubated at $37^{\circ} \mathrm{C}$ for $24 \mathrm{~h}$ for aggregation, which was verified by Western blotting and immunocytochemical staining (Figure 1A). The $A \beta_{1-42}$ peptide was dissolved in medium to final concentrations of $0.1,1$, and $10 \mu \mathrm{M}$ for cytotoxicity examination.

\subsection{Preparation of 4-PSB-2 Solution and Treatment}

In this study, 4-PSB-2 was provided by the Research Center of National Research Program for Biopharmaceuticals, Taiwan, and its structure is shown in Figure 1D. To verify the cytotoxicity of 4-PSB-2, it was dissolved in DMSO and medium to final concentrations of $1,25,50,100$, and $200 \mu \mathrm{M}$.

\subsection{Cell Viability Assay}

ARPE-19 cells were plated in 96-well plates containing 10\% FBS DMEM/F12 medium and cultured for $24 \mathrm{~h}$. ARPE-19 cell cytotoxicity was measured at oA $\beta_{1-42}$ doses of $0.1,1$, and $10 \mu \mathrm{M}$ and 4-PSB-2 doses of 1, 25, 50, 100, and $200 \mu \mathrm{M}$. Cell viability was measured by thiazolyl blue tetrazolium blue (MTT; Sigma-Aldrich, St. Louis, MO, USA). Briefly, $10 \mu \mathrm{L}$ of MTT solution $(5 \mathrm{mg} / \mathrm{mL})$ were added to each well and incubated for $3 \mathrm{~h}$ at $37^{\circ} \mathrm{C}$. After removing the supernatant, $100 \mu \mathrm{L}$ DMSO was added into each well. The intensity was measured colorimetrically at $570 \mathrm{~nm}$ with a microplate reader (Thermo Scientific Multiskan Spectrum, USA).

\subsection{Western Blot Analysis}

ARPE-19 cells were collected from 6-well plates and then homogenized in an ice-cold radioimmunoprecipitation assay (RIPA) lysis buffer containing phosphatase and protease inhibitors (F. Hoffmann-La Roche AG, Basel, Switzerland). The samples were sonicated and centrifuged for $15 \mathrm{~min}$ at $13,500 \times \mathrm{g}$ at $4{ }^{\circ} \mathrm{C}$. The supernatants were collected, and the protein concentration was measured with Bradford protein assay (Bio-Rad Laboratories, Hercules, CA, USA). Equal amounts of proteins from ARPE-19 cells were separated by $12 \%$ sodium dodecyl sulfate-polyacrylamide gel electrophoresis (SDS-PAGE) and transferred to nitrocellulose membranes. The membranes were blocked with $1 \%$ bovine serum albumin 
(BSA) for $1 \mathrm{~h}$ at room temperature and incubated overnight at $4{ }^{\circ} \mathrm{C}$ with the following primary antibodies: rabbit anti-TNF-alpha (1:1000, Abcam, Cambridge, UK), goat antiCOX-2 (1:500, Santa Cruz Biotechnology, Dallas, TX, USA), rabbit anti-iNOS (1:500, Thermo Fisher Scientific), rabbit anti-NF- $\mathrm{B}$ p 65 (1:1000, Santa Cruz Biotechnology), rabbit antiBECLIN I (1:200, Abcam), rabbit anti-LC3B I/II (1:200, Abcam), rabbit anti-p62 (1:200, Abcam), and mouse anti- $\beta$-actin (1:10,000, Sigma-Aldrich). After that, the membranes were washed three times with $1 \mathrm{X}$ phosphate-buffered saline (PBS) containing $0.1 \%$ Tween-20 and incubated with the corresponding conjugated antibodies, including a horseradish peroxidase-conjugated (HRP) anti-mouse antibody (1:10,000, Invitrogen, Carlsbad, CA, USA), HRP-conjugated goat anti-rabbit or anti-mouse antibody (1:10,000, Invitrogen), and HRP-conjugated donkey anti-goat antibody (1:10,000, Invitrogen), for $1 \mathrm{~h}$ at room temperature. The proteins of specific molecular weights were visualized using enhanced chemiluminescence reagents (Western Lightning ${ }^{\circledR}$ Plus-ECL, PerkinElmer, MA, USA) and detected by a UVP BioSpectrum 810 imaging system. Band intensity was quantified using ImageJ (downloaded from National Institutes of Health, Bethesda, MD, USA).

\subsection{Immunocytochemical Staining and Image Analysis}

ARPE-19 cells were seeded on coverslips overnight. After oA $\beta_{1-42}$ and/or 4-PSB-2 treatment for $24 \mathrm{~h}$, the cells were fixed with $4 \%$ paraformaldehyde and blocked with $2 \%$ bovine serum albumin. Then, the cells were incubated overnight at $4{ }^{\circ} \mathrm{C}$ with the following primary antibodies: rabbit anti-A $\beta$ oligomer (A11) (1:500, Thermo Fisher Scientific), rabbit anti-TNF- $\alpha$ (1:300, Abcam), goat anti-COX-2 (1:500, Santa Cruz Biotechnology), rabbit anti-iNOS (1:300, Thermo Fisher Scientific), and rabbit anti-NF-kB p65 (1:300, Santa Cruz Biotechnology). Then, they were incubated at room temperature for $1 \mathrm{~h}$ with the following secondary antibodies: Alexa 594- or Alexa 488-conjugated goat anti-rabbit IgG (1:300, Thermo Fisher Scientific) and Alexa 488-conjugated donkey anti-goat IgG (1:300, Thermo Fisher Scientific). After washing with PBS, the cells were counterstained with DAPI for 5 min, mounted with Fluoromount ${ }^{\mathrm{TM}}$ aqueous mounting medium, and observed under a fluorescence microscope (Nikon ECLIPSE Ni-E, Tokyo, Japan). For calculating the positive area, the percentage of each antibody $(450 \mu \mathrm{m} \times 450 \mu \mathrm{m})$ was quantified using ImageJ software.

\subsection{Statistical Analysis}

The mean \pm standard error of the mean (mean \pm SEM) were calculated and plotted. The data from the cell viability assay were analyzed by a two-tailed Mann-Whitney test. Western blotting and immunocytochemical staining data were analyzed by one-way ANOVA. Statistical significance for the differences among the groups was established at a $p$-value $<0.05$. All graphs were plotted with GraphPad Prism 8.0 software (San Diego, CA, USA).

\section{Conclusions}

In this study, we identified that 4-PSB-2 exhibits anti-inflammatory effects via NF- $\mathrm{kB}$ signaling in $\mathrm{oA} \beta_{1-42}$-treated ARPE-19 cells without notable side effects. Our results suggest a novel therapeutic approach to AMD.

Author Contributions: I.Y.L. and P.V. developed the hypotheses, designed and performed experiments, analyzed data, prepared Figures 1-4, and wrote the manuscript. S.-P.H. and S.C. developed the hypotheses, designed experiments, interpreted results, and provided technical support. Z.-H.W. helped to interpret results. All authors have read and agreed to the published version of the manuscript.

Funding: This research was supported by the Buddhist Tzu Chi Medical Foundation and Tzu Chi University grant "TCMMP 105-08-01", “TCMF-SP 108-04”, and Ministry of Science and Technology (MOST), Taiwan (MOST-107-2410-H320-DOI-MY3). 
Acknowledgments: We sincerely thank Rong Kung Tsai for providing ARPE-19 cells. We also thank Pavithra Suresh, Tanita Parojana, Sarayut Phasuk, Shao-Fang Liang, Hsien-Ting Huang, Kai-Chi Liang, Krishnamoorthy Vignesh, and Shimon Jude Swer for helpful suggestions and experimental assistance.

Conflicts of Interest: The authors declare no conflict of interest.

\section{References}

1. Pennington, K.L.; DeAngelis, M.M. Epidemiology of age-related macular degeneration (AMD): Associations with cardiovascular disease phenotypes and lipid factors. Eye Vis. 2016, 3, 34. [CrossRef] [PubMed]

2. Investigators, I.S.; Chakravarthy, U.; Harding, S.P.; Rogers, C.A.; Downes, S.M.; Lotery, A.J.; Wordsworth, S.; Reeves, B.C. Ranibizumab versus bevacizumab to treat neovascular age-related macular degeneration: One-year findings from the IVAN randomized trial. Ophthalmology 2012, 119, 1399-1411.

3. Group, C.R.; Martin, D.F.; Maguire, M.G.; Ying, G.S.; Grunwald, J.E.; Fine, S.L.; Jaffe, G.J. Ranibizumab and bevacizumab for neovascular age-related macular degeneration. N. Engl. J. Med. 2011, 364, 1897-1908.

4. Chiou, G.C.Y. Pharmacological treatment of dry age-related macular degeneration (AMD). Taiwan J. Ophthalmol. $2011,1,2-5$. [CrossRef]

5. Bruban, J.; Glotin, A.L.; Dinet, V.; Chalour, N.; Sennlaub, F.; Jonet, L.; An, N.; Faussat, A.M.; Mascarelli, F. Amyloid-beta(1-42) alters structure and function of retinal pigmented epithelial cells. Aging Cell 2009, 8, 162-177. [CrossRef]

6. Ohno-Matsui, K. Parallel findings in age-related macular degeneration and Alzheimer's disease. Prog. Retin. Eye Res. 2011, 30, 217-238. [CrossRef]

7. Simo, R.; Villarroel, M.; Corraliza, L.; Hernandez, C.; Garcia-Ramirez, M. The retinal pigment epithelium: Something more than a constituent of the blood-retinal barrier-implications for the pathogenesis of diabetic retinopathy. J. Biomed. Biotechnol. 2010, $2010,190724$. [CrossRef]

8. Holtkamp, G.M.; Kijlstra, A.; Peek, R.; de Vos, A.F. Retinal pigment epithelium-immune system interactions: Cytokine production and cytokine-induced changes. Prog. Retin. Eye Res. 2001, 20, 29-48. [CrossRef]

9. Wang, L.; Clark, M.E.; Crossman, D.K.; Kojima, K.; Messinger, J.D.; Mobley, J.A.; Curcio, C.A. Abundant lipid and protein components of drusen. PLoS ONE 2010, 5, e10329. [CrossRef]

10. Anderson, D.H.; Talaga, K.C.; Rivest, A.J.; Barron, E.; Hageman, G.S.; Johnson, L.V. Characterization of beta amyloid assemblies in drusen: The deposits associated with aging and age-related macular degeneration. Exp. Eye Res. 2004, 78, 243-256. [CrossRef]

11. Johnson, L.V.; Leitner, W.P.; Rivest, A.J.; Staples, M.K.; Radeke, M.J.; Anderson, D.H. The Alzheimer's A beta -peptide is deposited at sites of complement activation in pathologic deposits associated with aging and age-related macular degeneration. Proc. Natl. Acad. Sci. USA 2002, 99, 11830-11835. [CrossRef] [PubMed]

12. Glotin, A.L.; Debacq-Chainiaux, F.; Brossas, J.Y.; Faussat, A.M.; Treton, J.; Zubielewicz, A.; Toussaint, O.; Mascarelli, F. Prematurely senescent ARPE-19 cells display features of age-related macular degeneration. Free Radic. Biol. Med. 2008, 44, $1348-1361$. [CrossRef] [PubMed]

13. Feng, L.; Liao, X.; Zhang, Y.; Wang, F. Protective effects on age-related macular degeneration by activated autophagy induced by amyloid-beta in retinal pigment epithelial cells. Discov. Med. 2019, 27, 153-160. [PubMed]

14. Kurji, K.H.; Cui, J.Z.; Lin, T.; Harriman, D.; Prasad, S.S.; Kojic, L.; Matsubara, J.A. Microarray analysis identifies changes in inflammatory gene expression in response to amyloid-beta stimulation of cultured human retinal pigment epithelial cells. Investig. Ophthalmol. Vis. Sci. 2010, 51, 1151-1163. [CrossRef] [PubMed]

15. Dinet, V.; Bruban, J.; Chalour, N.; Maoui, A.; An, N.; Jonet, L.; Buret, A.; Behar-Cohen, F.; Klein, C.; Treton, J.; et al. Distinct effects of inflammation on gliosis, osmohomeostasis, and vascular integrity during amyloid beta-induced retinal degeneration. Aging Cell 2012, 11, 683-693. [CrossRef]

16. Maloney, S.C.; Fernandes, B.F.; Castiglione, E.; Antecka, E.; Martins, C.; Marshall, J.C.; Di Cesare, S.; Logan, P.; Burnier, M.N., Jr. Expression of cyclooxygenase-2 in choroidal neovascular membranes from age-related macular degeneration patients. Retina 2009, 29, 176-180. [CrossRef]

17. Cao, S.; Ko, A.; Partanen, M.; Pakzad-Vaezi, K.; Merkur, A.B.; Albiani, D.A.; Kirker, A.W.; Wang, A.; Cui, J.Z.; Forooghian, F.; et al. Relationship between systemic cytokines and complement factor $\mathrm{H}$ Y $402 \mathrm{H}$ polymorphism in patients with dry age-related macular degeneration. Am. J. Ophthalmol. 2013, 156, 1176-1183. [CrossRef]

18. Evereklioglu, C.; Er, H.; Doganay, S.; Cekmen, M.; Turkoz, Y.; Otlu, B.; Ozerol, E. Nitric oxide and lipid peroxidation are increased and associated with decreased antioxidant enzyme activities in patients with age-related macular degeneration. Doc. Ophthalmol. Adv. Ophthalmol. 2003, 106, 129-136. [CrossRef]

19. Mayer, A.M.; Rodriguez, A.D.; Taglialatela-Scafati, O.; Fusetani, N. Marine pharmacology in 2009-2011: Marine compounds with antibacterial, antidiabetic, antifungal, anti-inflammatory, antiprotozoal, antituberculosis, and antiviral activities; affecting the immune and nervous systems, and other miscellaneous mechanisms of action. Mar. Drugs 2013, 11, 2510-2573.

20. Lee, H.P.; Huang, S.Y.; Lin, Y.Y.; Wang, H.M.; Jean, Y.H.; Wu, S.F.; Duh, C.Y.; Wen, Z.H. Soft coral-derived lemnalol alleviates monosodium urate-induced gouty arthritis in rats by inhibiting leukocyte infiltration and iNOS, COX-2 and c-Fos protein expression. Mar. Drugs 2013, 11, 99-113. [CrossRef] 
21. Lin, Y.Y.; Jean, Y.H.; Lee, H.P.; Chen, W.F.; Sun, Y.M.; Su, J.H.; Lu, Y.; Huang, S.Y.; Hung, H.C.; Sung, P.J.; et al. A soft coral-derived compound, 11-epi-sinulariolide acetate suppresses inflammatory response and bone destruction in adjuvant-induced arthritis. PLoS ONE 2013, 8, e62926. [CrossRef] [PubMed]

22. Wen, Z.H.; Chao, C.H.; Wu, M.H.; Sheu, J.H. A neuroprotective sulfone of marine origin and the in vivo anti-inflammatory activity of an analogue. Eur. J. Med. Chem. 2010, 45, 5998-6004. [CrossRef] [PubMed]

23. Chen, N.F.; Huang, S.Y.; Lu, C.H.; Chen, C.L.; Feng, C.W.; Chen, C.H.; Hung, H.C.; Lin, Y.Y.; Sung, P.J.; Sung, C.S.; et al. Flexibilide obtained from cultured soft coral has anti-neuroinflammatory and analgesic effects through the upregulation of spinal transforming growth factor-beta1 in neuropathic rats. Mar. Drugs 2014, 12, 3792-3817. [CrossRef] [PubMed]

24. Wu, S.Y.; Wang, H.M.; Wen, Y.S.; Liu, W.; Li, P.H.; Chiu, C.C.; Chen, P.C.; Huang, C.Y.; Sheu, J.H.; Wen, Z.H. 4-(phenylsulfanyl)butan2-one suppresses melanin synthesis and melanosome maturation in vitro and in vivo. Int. J. Mol. Sci. 2015, 16, 20240-20257. [CrossRef] [PubMed]

25. Chien, J.Y.; Sheu, J.H.; Wen, Z.H.; Tsai, R.K.; Huang, S.P. Neuroprotective effect of 4-(phenylsulfanyl)butan-2-one on optic nerve crush model in rats. Exp. Eye Res. 2016, 143, 148-157. [CrossRef]

26. Ratnayaka, J.A.; Serpell, L.C.; Lotery, A.J. Dementia of the eye: The role of amyloid beta in retinal degeneration. Eye 2015, 29, 1013-1026. [CrossRef]

27. Mitter, S.K.; Rao, H.V.; Qi, X.; Cai, J.; Sugrue, A.; Dunn, W.A., Jr.; Grant, M.B.; Boulton, M.E. Autophagy in the retina: A potential role in age-related macular degeneration. Adv. Exp. Med. Biol. 2012, 723, 83-90.

28. Golestaneh, N.; Chu, Y.; Xiao, Y.Y.; Stoleru, G.L.; Theos, A.C. Dysfunctional autophagy in RPE, a contributing factor in age-related macular degeneration. Cell Death Dis. 2017, 8, e2537. [CrossRef]

29. Snow, W.M.; Albensi, B.C. Neuronal Gene Targets of NF-kappaB and their dysregulation in Alzheimer's disease. Front. Mol. Neurosci. 2016, 9, 118. [CrossRef]

30. Song, S.B.; Tung, N.H.; Quang, T.H.; Ngan, N.T.; Kim, K.E.; Kim, Y.H. Inhibition of TNF-alpha-mediated NF-kappaB transcriptional activity in HepG2 cells by dammarane-type saponins from panax ginseng leaves. J. Ginseng Res. 2012, 36, 146-152. [CrossRef]

31. Cao, L.; Liu, C.; Wang, F.; Wang, H. SIRT1 negatively regulates amyloid-beta-induced inflammation via the NF-kappaB pathway. Braz. J. Med Biol. Res. 2013, 46, 659-669. [CrossRef] [PubMed]

32. Masuda, N.; Tsujinaka, H.; Hirai, H.; Yamashita, M.; Ueda, T.; Ogata, N. Effects of concentration of amyloid beta (Abeta) on viability of cultured retinal pigment epithelial cells. BMC Ophthalmol. 2019, 19, 70. [CrossRef] [PubMed]

33. Kivinen, N. The role of autophagy in age-related macular degeneration. Acta ophthalmologica 2018, 96 (Suppl. A110), 1-50. [CrossRef] [PubMed]

34. Chernykh, V.; Shevchenko, A.; Konenkov, V.; Prokofiev, V.; Eremina, A.; Trunov, A. TNF-alpha gene polymorphisms: Association with age-related macular degeneration in Russian population. Int. J. Ophthalmol. 2019, 12, 25-29. [PubMed]

35. Sedger, L.M.; McDermott, M.F. TNF and TNF-receptors: From mediators of cell death and inflammation to therapeutic giantsPast, present and future. Cytokine Growth Factor Rev. 2014, 25, 453-472. [CrossRef] [PubMed]

36. Touhami, S.; Beguier, F.; Augustin, S.; Charles-Messance, H.; Vignaud, L.; Nandrot, E.F.; Reichman, S.; Forster, V.; Mathis, T.; Sahel, J.A.; et al. Chronic exposure to tumor necrosis factor alpha induces retinal pigment epithelium cell dedifferentiation. J. Neuroinflamm. 2018, 15, 85. [CrossRef]

37. Chen, L.; Bai, Y.; Zhao, M.; Jiang, Y. TLR4 inhibitor attenuates amyloid-beta-induced angiogenic and inflammatory factors in ARPE-19 cells: Implications for age-related macular degeneration. Mol. Med. Rep. 2016, 13, 3249-3256. [CrossRef]

38. Chin, M.S.; Nagineni, C.N.; Hooper, L.C.; Detrick, B.; Hooks, J.J. Cyclooxygenase-2 gene expression and regulation in human retinal pigment epithelial cells. Investig. Ophthalmol. Vis. Sci. 2001, 42, 2338-2346.

39. Zhang, R.; Liu, Z.; Zhang, H.; Zhang, Y.; Lin, D. The COX-2-selective antagonist (NS-398) inhibits choroidal neovascularization and subretinal fibrosis. PLoS ONE 2016, 11, e0146808. [CrossRef]

40. Hattenbach, L.O.; Falk, B.; Nurnberger, F.; Koch, F.H.; Ohrloff, C. Detection of inducible nitric oxide synthase and vascular endothelial growth factor in choroidal neovascular membranes. Ophthalmologica 2002, 216, 209-214. [CrossRef]

41. Lee, J.; Rhee, M.H.; Kim, E.; Cho, J.Y. BAY 11-7082 is a broad-spectrum inhibitor with anti-inflammatory activity against multiple targets. Mediat. Inflamm. 2012, 2012, 416036. [CrossRef] [PubMed] 